\title{
Decision Support System for Determination of Village Fund Allocation Using AHP Method
}

\author{
Vasma Vitriani Sianipar ${ }^{1, *}$, Anjar Wanto ${ }^{1}$, M Safii $^{2}$ \\ ${ }^{1}$ Department of Computer Science, STIKOM Tunas Bangsa, Pematangsiantar, Indonesia \\ ${ }^{2}$ Department of Computerized Accounting, AMIK Tunas Bangsa, Pematangsiantar, Indonesia \\ Email: ${ }^{1 *}$ sianiparvasma@gmail.com, ${ }^{2}$ anjarwanto@amiktunasbangsa.ac.id, ${ }^{3}$ m.safii @ amiktunasbangsa.ac.id
}

\begin{abstract}
This study aims to describe the management of the allocation of village funds in physical development in the village of Siborna, Panei Subdistrict, Simalungun Regency and to identify inhibiting factors and supporting factors in managing village fund allocation. The focus of this research is the management of village fund allocations which include: planning, implementation. The determination of the allocation of village funds will later use the Analytical Hierarchy Process (AHP) method with 4 criteria including: villagers, rural poor, village area and Village Geographical Difficulty Index. Alternative Samples in this study were 4 villages, including the villages of Sosor Hamlet, Simpang Bahbirong Hamlet, Hutabagasan Hamlet and Kebun Sayur Hamlet. The results of this study using the AHP method obtained by the Village of Vegetable Farm Village is an alternative with the highest value that is eligible to get a village fund allocation from the government with a value of 3,0000.
\end{abstract}

Keywords: DSS, Village Fund, AHP, Siborna Village, Panei District

\section{INTRODUCTION}

The new paradigm in terms of development today, prefers Village Government with autonomy as a logical consequence of the existence of authority and an important role of the village is the availability of sufficient funds. One source of revenue stipulated in Law number 32 of 2004 concerning regional government is part of the central and regional financial balance funds received by the Regency / city which is the Village Fund Allocation.

Progress can be seen from three aspects, namely the level of income, growth, and income development, and income distribution. The three aspects of income in the economy and its activities are regulated and implemented in a planned manner so that it runs in a balanced manner which ultimately results in steady and dynamic economic stability. The policy that has been implemented is the removal of development resources related to poverty reduction. Therefore this research will discuss about determining the allocation of village funds with a case study taken at Nagori Siborna, Panei District, Simalungun Regency. This is done to assist village officials in making decisions, therefore to avoid mistakes in determining the allocation of village funds, we need a system that can help determine the allocation of village funds effectively and efficiently. There are many branches in the field of computer science that are able to solve complex problems, this is evident from the many studies that have been done, such as research in the field of data mining [1]-[8], the field of artificial neural networks [9]-[21], as well as the field of decision support systems [22]-[29]. Based on this explanation, researchers used a decision support system to resolve the above problem. In this case, the researcher uses the Analytical Hierarchy Process (AHP) method, because this method can be used for very complex decision making problems, in which there are criteria and sub-criteria levels.

Many previous studies discuss the AHP method, including research for selecting suppliers using fuzzy AHP and TOPSIS: a case study in the Indian automotive industry. This article has illustrated a case study for the supplier of headlight selection in a leading car company in India. Eight criteria were investigated in the context of the supplier selection problem. In addition, this study highlights two valuable contributions: (a) the comprehensive structure of this paper is to overcome the problem of supplier selection, in this context a hybrid AHP-TOPSIS methodology has been used to determine the relative importance of factor supplier selection through the Saaty scale. (b) Thus, there are limited studies of the hybrid MCDM (AHP-TOPSIS) method for investigating supplier selection problems [30]. Other studies discuss the D-AHP method with different information credibility. In this paper, the problem of MCDM has been studied using the D-AHP method in which the credibility of providing information is analyzed numerically. The results show that information credibility has little impact on alternative rankings, and the weight of alternative priorities has been influenced to a relatively clear level. In future research, criteria for measuring the credibility of information will be studied [31]. Next research that discusses the scheduling of time-sensitive leases in the cloud computing environment using AHP [32], and research that discusses risk evaluation using a new hybrid method based on the FMEA method, extended MULTIMOORA, and AHP in a fuzzy environment [33]. Based on this background, the research was conducted. It is expected that using this AHP method, results will be obtained in the form of recommendations for determining Village Fund Allocation effectively and efficiently. 


\section{RESEARCH METHODS}

In determining the selection of a good allocation of village funds requires the right tools, which use computers as a means that can help human resources to get a lot of information precisely and accurately with a method and systematic calculation that is the AHP method, this method can provide alternative choices . Basically AHP is a method for solving a complex problem and not structured into groups, organizing groups into a hierarchy.

\subsection{Method of collecting data}

Data collection methods used in general to solve problems in this study are:

a. Library Research is to use library as a means of collecting data, by studying books as reference material relating to cases raised by researchers.

b. Field Work Research is research conducted directly in the field using several techniques such as:

1. Observation: The method of collecting data by making direct observations of various existing activities. This is done by the writer direct observation in the research location to find the data needed in this study such as taking alternative samples and assessment criteria to be tested.

2. Documentation: Data collection is carried out to obtain secondary data from documents or archives relevant to this research. This is done by the writer making an alternative sample assessment document against the criteria previously discussed during the interview session.

\subsection{Flowchart Program}

Flowchart program merupakan simbol-simbol yang menerangkan bagaimana suatu program berjalan dari awal hingga akhir.

\subsubsection{AHP Method Flowchart}

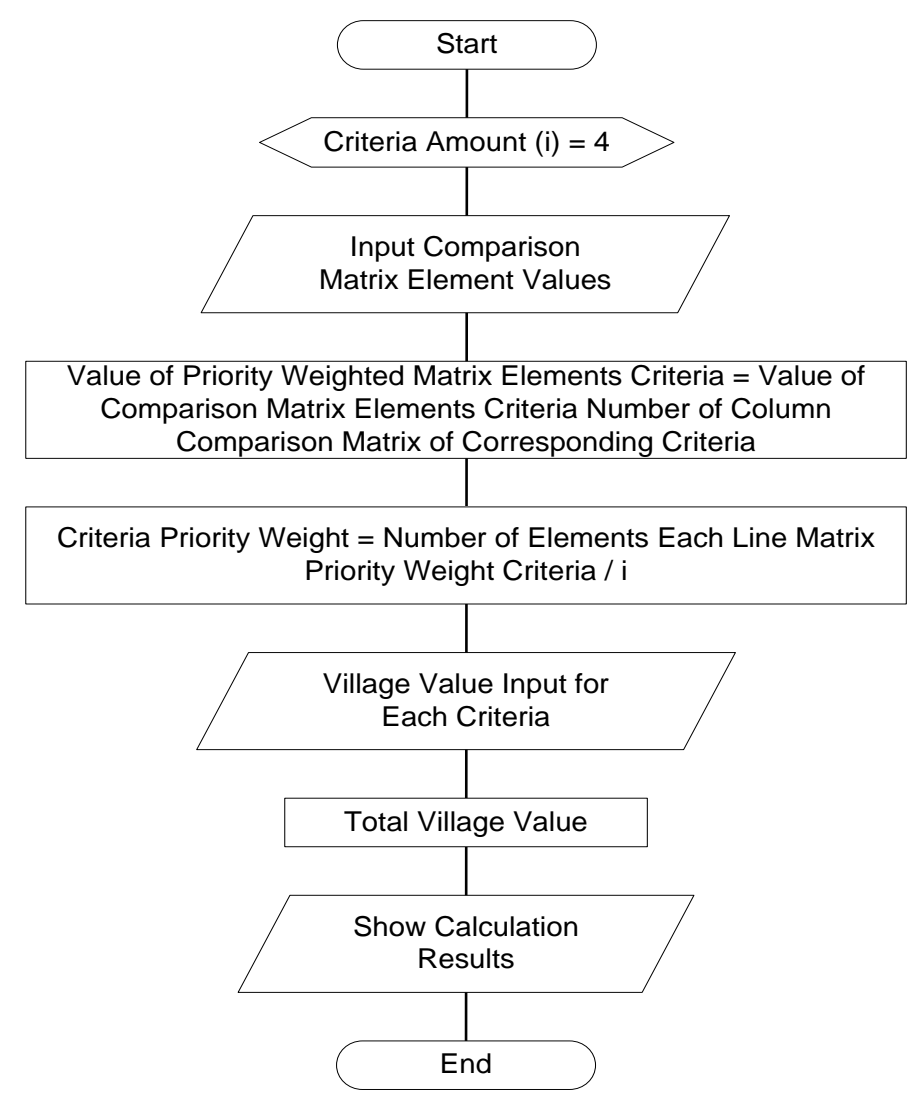

Figure 1. AHP Method Flowchart

\subsubsection{Flowchart System}

This section shows the workflow or what is being done in the system as a whole and explains the sequence of procedures contained in the system. This flowchart includes a graphical representation of the sequence of procedures that form a system. System flowcharts consist of data flowing through the system and the processes that transform the data. 


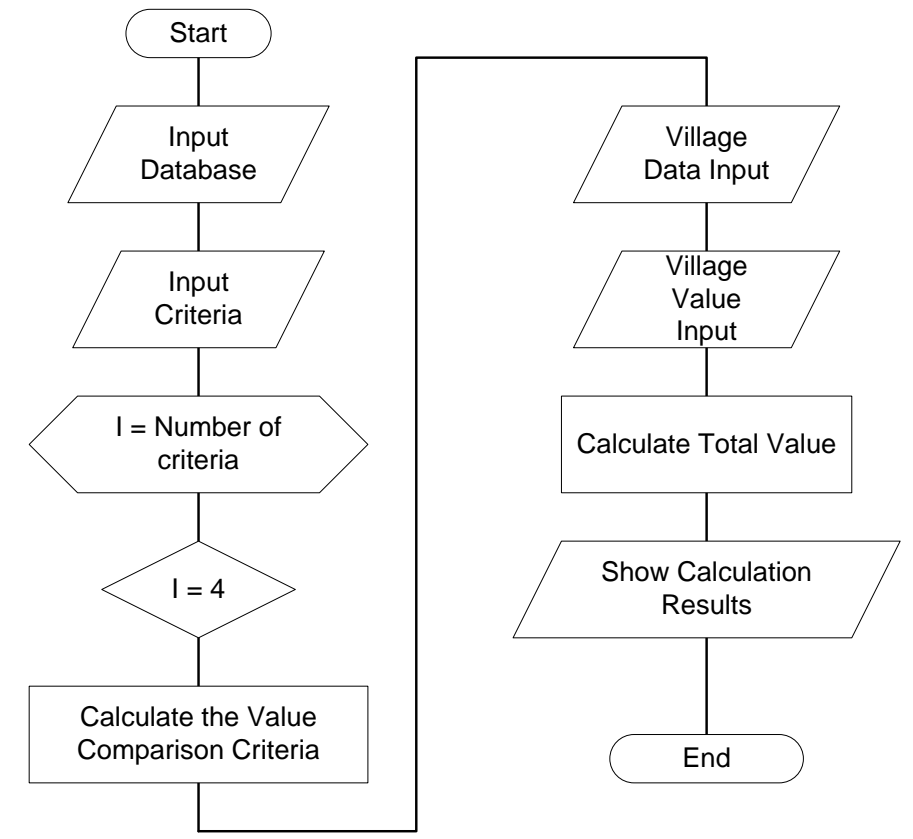

Figure 2. Flowchart System

\section{RESULT AND DISCUSSION}

The calculation steps using the AHP method are as follows:

1. Determine the types of criteria to be considered in the village selection decision support system, the village establishes the criteria used as a reference in decision making namely the villagers, the rural poor, the area of the village, the Geographic Difficulty Index. Then the three criteria are compared one by one, which in AHP terms is called pair-wise comparation.

a. Villagers are more important 1 time than poor villagers

b. The rural poor are 3 times more important than the village area

c. The area of the village is 5 times more important than the Geographic Difficulty Index

d. The Geographical Difficulty Index is twice as important as the villagers

2. Arrange a hierarchy which starts with the objectives and then the criteria at the lower levels. The order of the hierarchy can be seen in the figure below:

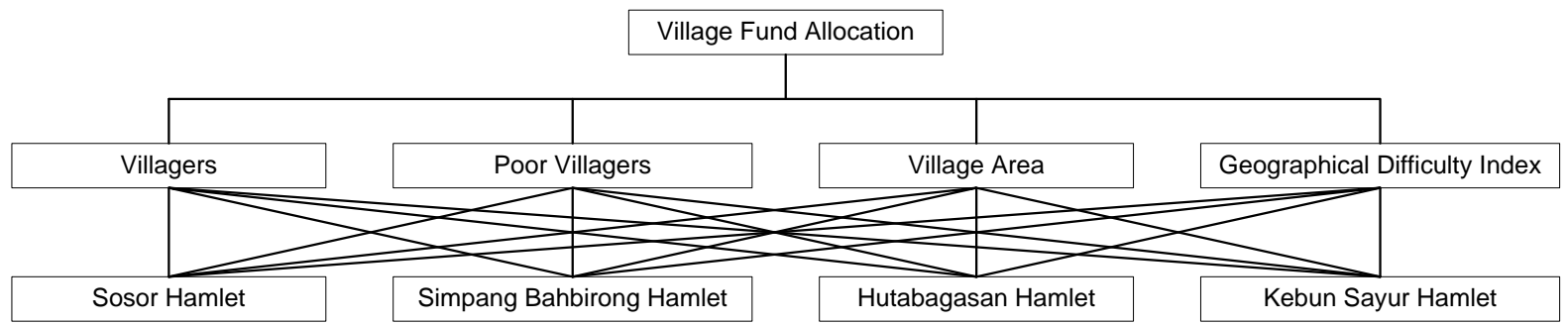

Figure 3. System Hierarchy Order

3. After compiling the hierarchy above the next step is to calculate the consistency of comparison of each criterion based on the level of need or level of importance between one criterion with the other criteria using the AHP method. The matrix diagonal value for comparison of elements with the element itself is filled with the value (1) while the contents of the comparison value between 1 and 9 are the opposite. Comparison between one criterion with another can be seen in the comparison matrix below:

Table 1. Criteria Comparison Matrix

\begin{tabular}{lcccc}
\hline \multicolumn{1}{c}{ Criteria } & Villagers & Poor Villagers & Village Area & $\begin{array}{c}\text { Geographical } \\
\text { Difficulty Index }\end{array}$ \\
\hline Villagers & 1 & 1 & 1 & 1 \\
Poor Villagers & 1 & 1 & 3 & 1 \\
\hline
\end{tabular}




\begin{tabular}{lcccc}
\hline \multicolumn{1}{c}{ Criteria } & Villagers & Poor Villagers & Village Area & $\begin{array}{c}\text { Geographical } \\
\text { Difficulty Index }\end{array}$ \\
\hline Village Area & 1 & 1 & 1 & 5 \\
Geographical Difficulty Index & 2 & 1 & 1 & 1 \\
\hline Amount & 5 & 4 & 6 & 8 \\
\hline
\end{tabular}

4. Calculate the Priority Criteria Matrix. At this stage priority criteria will be sought to later determine whether values are included in the appropriate matrix. The value in the matrix is obtained by dividing the row column value by the number. Priority is obtained by dividing each row by the number of matrices.

Table 2. Priority Comparison Criteria Matrix

\begin{tabular}{lcccccc}
\hline \multicolumn{1}{c}{ Criteria } & Villagers & $\begin{array}{c}\text { Poor } \\
\text { Villagers }\end{array}$ & $\begin{array}{c}\text { Village } \\
\text { Area }\end{array}$ & $\begin{array}{c}\text { Geographical } \\
\text { Difficulty Index }\end{array}$ & Amount & Priority \\
\hline Villagers & 0.2 & 0.25 & 0.16 & 0.12 & 0.74 & 0.18 \\
Poor Villagers & 0.2 & 0.25 & 0.5 & 0.12 & 1.07 & 0.26 \\
Village Area & 0.2 & 0.25 & 0.16 & 0.62 & 1.24 & 0.31 \\
Geographical Difficulty Index & 0.4 & 0.25 & 0.16 & 0.12 & 0.94 & 0.23 \\
\hline
\end{tabular}

5. Calculates the criteria addition matrix. The value in the matrix is obtained by multiplying the row column values in the matrix table comparing the criteria with the priority of each criterion.

Table 3. Addition Matrix for Each Line

\begin{tabular}{lccccc}
\hline \multicolumn{1}{c}{ Criteria } & Villagers & $\begin{array}{c}\text { Poor } \\
\text { Villagers }\end{array}$ & $\begin{array}{c}\text { Village } \\
\text { Area }\end{array}$ & $\begin{array}{c}\text { Geographical } \\
\text { Difficulty Index }\end{array}$ & Amount \\
\hline Villagers & 0.18 & 0.18 & 0.18 & 0.18 & 0.74 \\
Poor Villagers & 0.26 & 0.26 & 0.80 & 0.26 & 1.61 \\
Village Area & 0.31 & 0.31 & 0.31 & 1.55 & 0.24 \\
Geographical Difficulty Index & 0.47 & 0.23 & 0.23 & 0.23 & 1.17 \\
\hline
\end{tabular}

6. Calculate the consistency ratio matrix.

Table 4. Consistent Ratio Matrix

\begin{tabular}{lccc}
\hline \multicolumn{1}{c}{ Criteria } & Number of Rows & Priority & Results \\
\hline Villagers & 0.18 & 0.18 & 0.18 \\
Poor Villagers & 0.26 & 0.26 & 0.80 \\
Village Area & 0.31 & 0.31 & 0.31 \\
Geographical Difficulty Index & 0.47 & 0.23 & 0.23 \\
\hline
\end{tabular}

Number of ratios $=7.0139$

Criteria Amount $(\mathrm{n})=4$

$\lambda$ maks $=$ Number of ratios $/ \mathrm{n}=7.01 / 4=1.7535$

$\mathrm{C} 1=(\lambda$ maks-n $) /(\mathrm{n}-1)=(1.75-4) /(4-1)=-0.7488$

$\mathrm{CR}=\mathrm{C} 1 / \mathrm{R} 1=-0.7488 / 0.90=-0.8320$

Because of value CR (Consistency Ratio) from the criteria, -0.8320 then the consistency ratio of the calculation is acceptable.

7. After getting the priority weight value, it can find the total value with the value of each village criteria multiplied by the corresponding priority weight value. For example village data in the table below:

Table 5. Consistent Ratio Matrix

\begin{tabular}{lcccc}
\hline \multicolumn{1}{c}{ Villages Name } & Villagers & $\begin{array}{c}\text { Poor } \\
\text { Villagers }\end{array}$ & Village Area & $\begin{array}{c}\text { Geographical Difficulty } \\
\text { Index }\end{array}$ \\
\hline Sosor Hamlet & 2 & 3 & 2 & 2 \\
Simpang Bahbirong Hamlet & 2 & 2 & 2 & 2 \\
Hutabagasan Hamlet & 2 & 2 & 3 & 2 \\
Kebun Sayur Hamlet & 3 & 3 & 3 & 3 \\
\hline
\end{tabular}

Total value Sosor Hamlet

Total value Simpang Bahbirong Hamlet

Total value Hutabagasan Hamlet

Total value Kebun Sayur Hamlet

$$
\begin{aligned}
& =(2 \times 0.18)+(3 \times 0.29)+(2 \times 0.21)+(2 \times 0.31)=2.28 \\
& =(2 \times 0.18)+(2 \times 0.29)+(2 \times 0.21)+(2 \times 0.31)=2.00 \\
& =(2 \times 0.18)+(2 \times 0.29)+(3 \times 0.21)+(2 \times 0.31)=2.15 \\
& =(3 \times 0.18)+(3 \times 0.29)+(3 \times 0.21)+(3 \times 0.31)=3.00
\end{aligned}
$$


The IJICS (International Journal of Informatics and Computer Science) Vol 4 No 1, March 2020

ISSN 2548-8384 (online) ISSN 2548-8449 (print)

Page $20-28$

DOI 10.30865/ijics.v4i1.2101

Table 6. Total Village Value

\begin{tabular}{lccccc}
\hline \multicolumn{1}{c}{ Villages Name } & Villagers & $\begin{array}{c}\text { Poor } \\
\text { Villagers }\end{array}$ & $\begin{array}{c}\text { Village } \\
\text { Area }\end{array}$ & $\begin{array}{c}\text { Geographical } \\
\text { Difficulty Index }\end{array}$ & Amount \\
\hline Sosor Hamlet & 2 & 3 & 2 & 2 & 2.28 \\
Simpang Bahbirong Hamlet & 2 & 2 & 2 & 2 & 2.00 \\
Hutabagasan Hamlet & 2 & 2 & 3 & 2 & 2.15 \\
Kebun Sayur Hamlet & $\mathbf{3}$ & $\mathbf{3}$ & $\mathbf{3}$ & $\mathbf{3}$ & $\mathbf{3 . 0 0}$ \\
\hline
\end{tabular}

\section{IMPLEMENTATION}

The following is an overview of the implementation of the Village Fund Allocation Decision Support System in Nagori Siborna Using the AHP Method as follows:

1. Login Form

Login Form is given for user convenience for system security that has been designed.

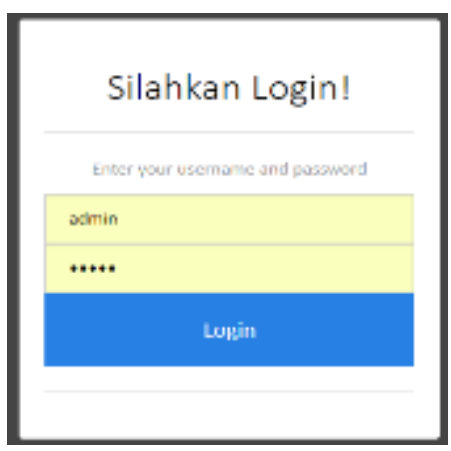

Figure 4. Login Form

2. Main Menu

The main menu in this application consists of 7 sections, namely Main, village data, Criteria data, Rating, Calculation, Reports, and Login Settings where each menu will consist of several sub menus. Display the main menu design can be seen in the following figure:

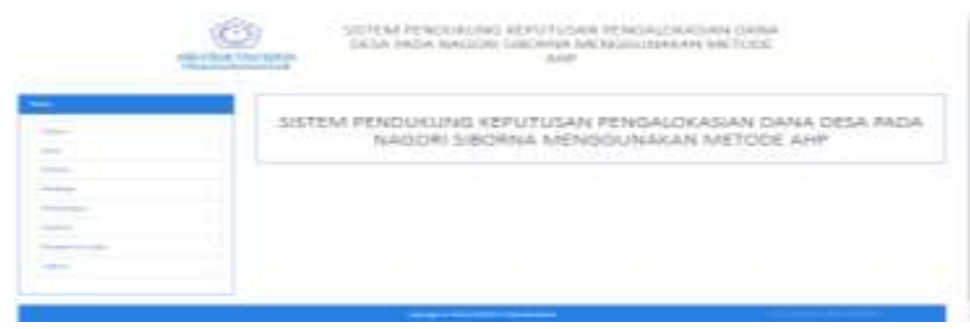

Figure 5. Main Menu

3. Village Form

Village data input is the main data needed by the system. The data will be declared as valuation alternatives.

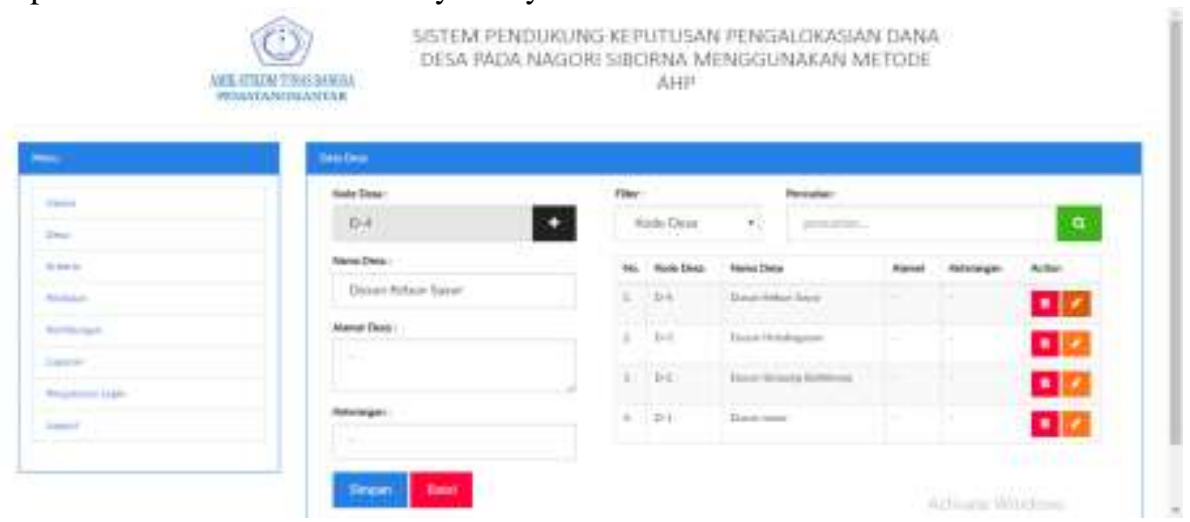

Figure 6. Form Villages 
The IJICS (International Journal of Informatics and Computer Science) Vol 4 No 1, March 2020

ISSN 2548-8384 (online) ISSN 2548-8449 (print)

Page $20-28$

DOI 10.30865/ijics.v4i1.2101

\section{Criteria Form}

Input data values This input criteria serves to provide a preference value for the level of satisfaction of the criteria assessed according to the AHP method.

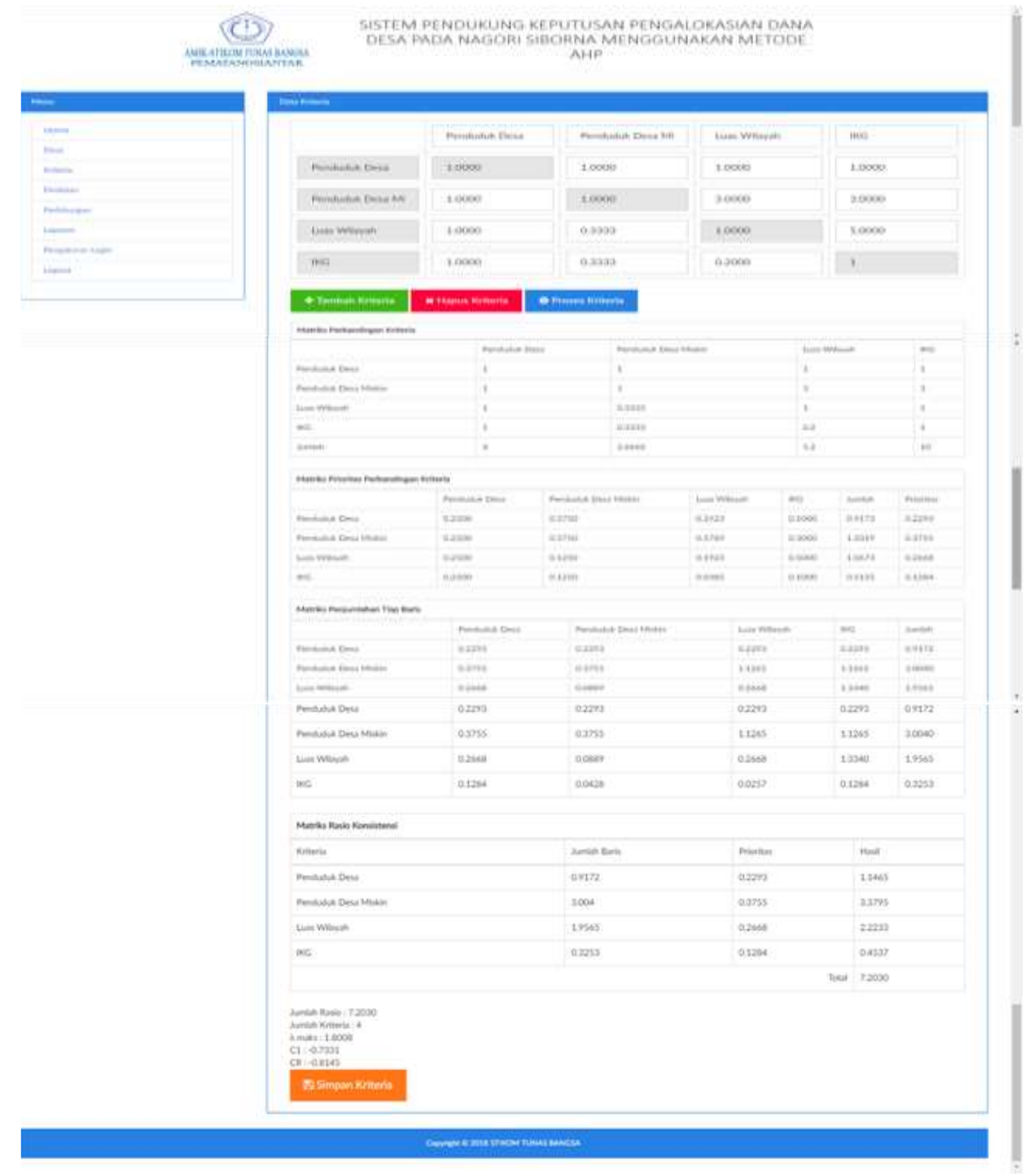

Figure 7. Criteria Form

5. Scoring Form

In this decision assessment process form, where data for each alternative entered is calculated using the AHP process so as to produce the total value processed and the level of satisfaction.

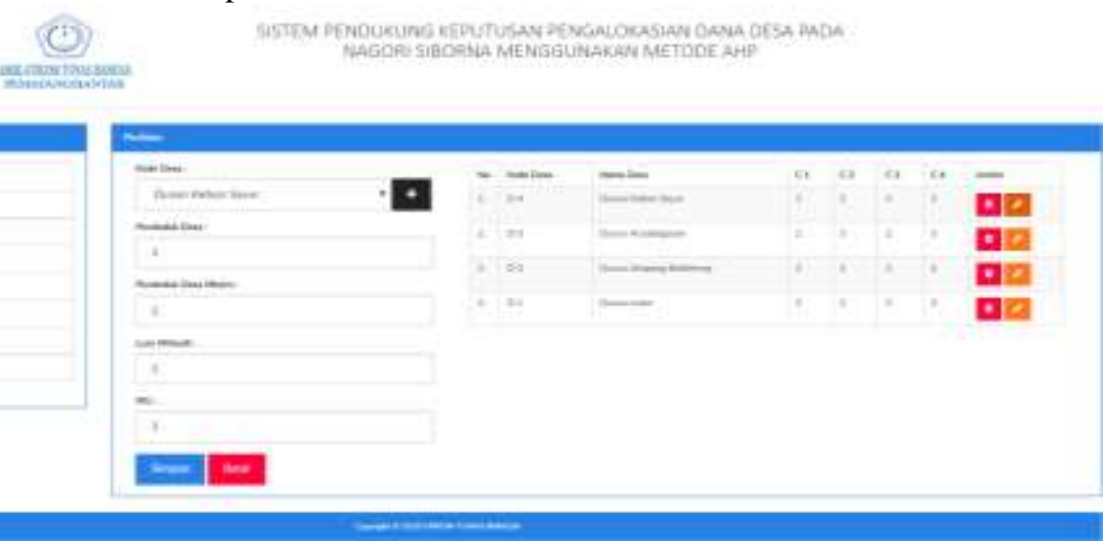

Figure 8. Scoring Form 
The IJICS (International Journal of Informatics and Computer Science) Vol 4 No 1, March 2020

ISSN 2548-8384 (online) ISSN 2548-8449 (print)

Page $20-28$

DOI 10.30865/ijics.v4i1.2101

6. Calculation Form

This calculation form serves to display the results of each village and is processed into the application using the AHP method. To display the calculation form can be seen in the following figure:

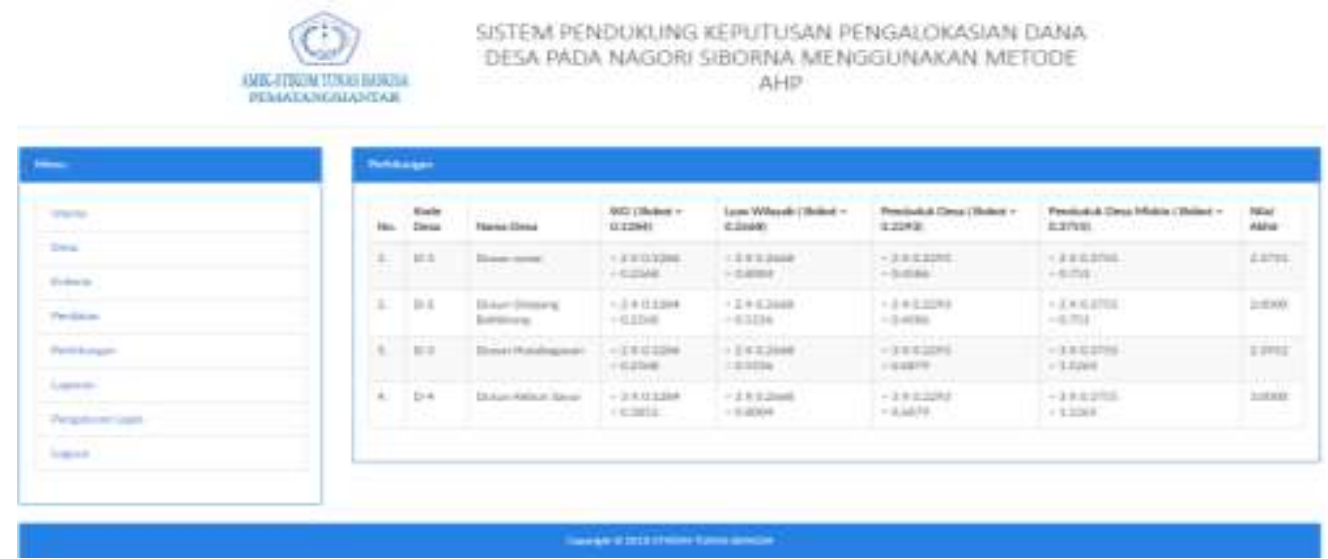

Figure 9. Calculation Form

7. Results Report

The Results Report serves to see the results of all calculations using the AHP method and can see the final results so that it can be seen the best alternative.

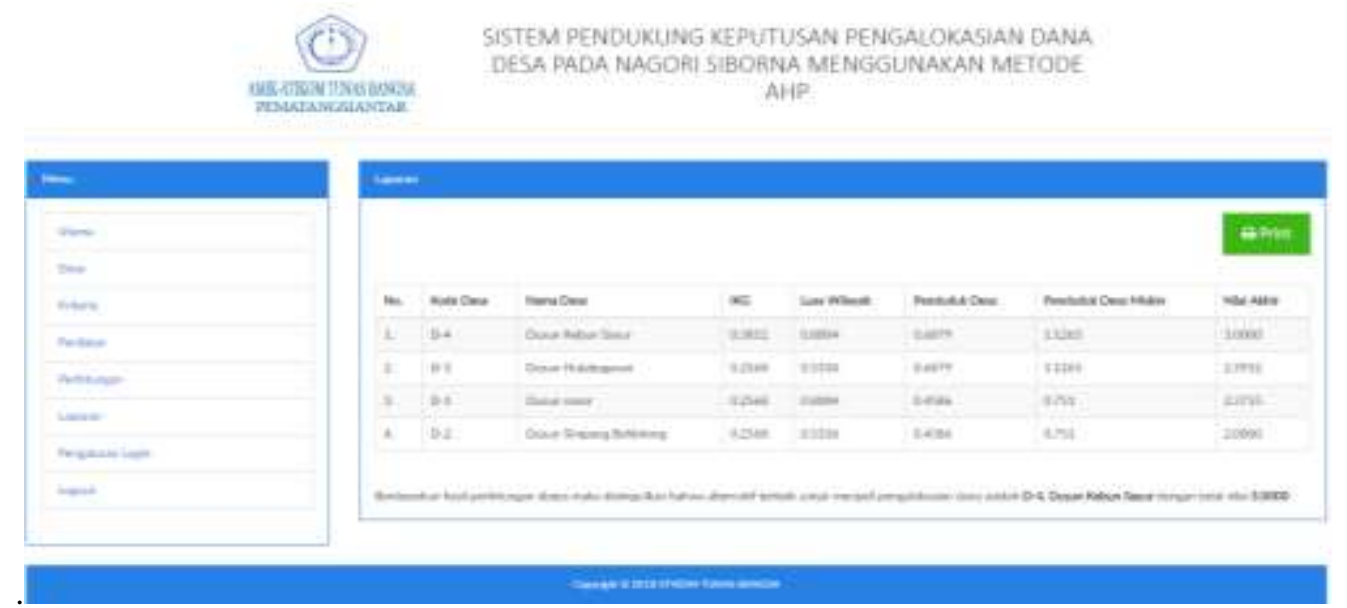

Figure 10. Result Report Form

8. Final Report

The final report is to see the final results of all calculations using the AHP method.

Laporan

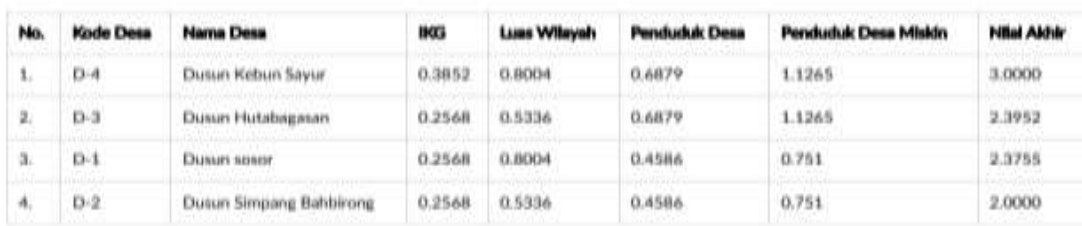

Figure 11. Final Report

Based on the results of the calculation, it was concluded that the best alternative that received the allocation of village funds was D-4, Kebun Sayur Hamlet.

\section{CONCLUSION}

Conclusions that can be elaborated from this study include: 
1. The Analytical Hierarchy Process (AHP) method can be applied well to the Decision Support System (SPK) in the case of determining the allocation of the Nagori Siborna Village Fund.

2. From this decision support system the user can determine the recipient of the Village Fund in Nagori Siborna based on the final preference value, where if the preference value is greater, then for the determination of the more feasible and if the preference value is smaller, then for determining the allocation of the Nagori Siborna Village Fund is not feasible.

3. The final results obtained using either manual or computerized calculations show the same results, namely 1 hamlet selected as the best criterion in determining the receipt of village fund allocations.

\section{REFERENCES}

[1] R. Rahim et al., "C4.5 Classification Data Mining for Inventory Control," International Journal of Engineering \& Technology, vol. 7, pp. 68-72, 2018.

[2] I. Parlina et al., "Naive Bayes Algorithm Analysis to Determine the Percentage Level of visitors the Most Dominant Zoo Visit by Age Category," Journal of Physics: Conference Series, vol. 1255, no. 1, 2019.

[3] I. S. Damanik, A. P. Windarto, A. Wanto, Poningsih, S. R. Andani, and W. Saputra, "Decision Tree Optimization in C4.5 Algorithm Using Genetic Algorithm," Journal of Physics: Conference Series, vol. 1255 , no. 1 , pp. 1-7, 2019.

[4] H. Siahaan, H. Mawengkang, S. Efendi, A. Wanto, and A. Perdana Windarto, "Application of Classification Method C4.5 on Selection of Exemplary Teachers," Journal of Physics: Conference Series, vol. 1235 , no. $1,2019$.

[5] D. Hartama, A. Perdana Windarto, and A. Wanto, "The Application of Data Mining in Determining Patterns of Interest of High School Graduates," Journal of Physics: Conference Series, vol. 1339, no. 1, pp. $1-6,2019$.

[6] M. Widyastuti, A. G. Fepdiani Simanjuntak, D. Hartama, A. P. Windarto, and A. Wanto, "Classification Model C.45 on Determining the Quality of Custumer Service in Bank BTN Pematangsiantar Branch," Journal of Physics: Conference Series, vol. 1255, no. 012002, pp. 1-6, 2019.

[7] W. Katrina, H. J. Damanik, F. Parhusip, D. Hartama, A. P. Windarto, and A. Wanto, "C.45 Classification Rules Model for Determining Students Level of Understanding of the Subject," Journal of Physics: Conference Series, vol. 1255, no. 012005, pp. 1-7, 2019.

[8] S. Sudirman, A. P. Windarto, and A. Wanto, "Data Mining Tools | RapidMiner: K-Means Method on Clustering of Rice Crops by Province as Efforts to Stabilize Food Crops In Indonesia," IOP Conference Series: Materials Science and Engineering, vol. 420, no. 012089, pp. 1-8, 2018.

[9] E. Siregar, H. Mawengkang, E. B. Nababan, and A. Wanto, "Analysis of Backpropagation Method with Sigmoid Bipolar and Linear Function in Prediction of Population Growth," Journal of Physics: Conference Series, vol. 1255 , no. 1, pp. 1-6, 2019.

[10] G. W. Bhawika et al., "Implementation of ANN for Predicting the Percentage of Illiteracy in Indonesia by Age Group," Journal of Physics: Conference Series, vol. 1255, no. 1, pp. 1-6, 2019.

[11] W. Saputra, J. T. Hardinata, and A. Wanto, "Resilient method in determining the best architectural model for predicting open unemployment in Indonesia," IOP Conference Series: Materials Science and Engineering, vol. 725, no. 1, pp. 1-7, 2020.

[12] A. Wanto and J. T. Hardinata, "Estimations of Indonesian poor people as poverty reduction efforts facing industrial revolution 4 . 0," IOP Conference Series: Materials Science and Engineering, vol. 725, no. 1, pp. $1-8,2020$.

[13] A. Wanto et al., "Model of Artificial Neural Networks in Predictions of Corn Productivity in an Effort to Overcome Imports in Indonesia,” Journal of Physics: Conference Series, vol. 1339, no. 1, pp. 1-6, 2019.

[14] A. Wanto et al., "Analysis of the Accuracy Batch Training Method in Viewing Indonesian Fisheries Cultivation Company Development," Journal of Physics: Conference Series, vol. 1255, no. 1, pp. 1-6, 2019.

[15] I. S. Purba et al., "Accuracy Level of Backpropagation Algorithm to Predict Livestock Population of Simalungun Regency in Indonesia Accuracy Level of Backpropagation Algorithm to Predict Livestock Population of Simalungun Regency in Indonesia," Journal of Physics: Conference Series, vol. 1255, no. 1, pp. 1-6, 2019.

[16] P. Parulian et al., "Analysis of Sequential Order Incremental Methods in Predicting the Number of Victims Affected by Disasters," Journal of Physics: Conference Series, vol. 1255, no. 1, pp. 1-6, 2019.

[17] A. Wanto et al., "Analysis of the Backpropagation Algorithm in Viewing Import Value Development Levels Based on Main Country of Origin," Journal of Physics: Conference Series, vol. 1255, no. 1, pp. 1- 
6, 2019.

[18] S. Setti, A. Wanto, M. Syafiq, A. Andriano, and B. K. Sihotang, “Analysis of Backpropagation Algorithms in Predicting World Internet Users,” Journal of Physics: Conference Series, vol. 1255, no. 1, pp. 1-6, 2019.

[19] T. Afriliansyah et al., "Implementation of Bayesian Regulation Algorithm for Estimation of Production Index Level Micro and Small Industry," Journal of Physics: Conference Series, vol. 1255, no. 1, pp. 1-6, 2019.

[20] A. Wanto et al., "Forecasting the Export and Import Volume of Crude Oil , Oil Products and Gas Using ANN," Journal of Physics: Conference Series, vol. 1255, no. 1, pp. 1-6, 2019.

[21] M. K. Z. Sormin, P. Sihombing, A. Amalia, A. Wanto, D. Hartama, and D. M. Chan, "Predictions of World Population Life Expectancy Using Cyclical Order Weight / Bias," Journal of Physics: Conference Series, vol. 1255, no. 1, pp. 1-6, 2019.

[22] P. P. P. A. N. . F. I. R.H Zer, Masitha, A. P. Windarto, and A. Wanto, "Analysis of the ELECTRE Method on the Selection of Student Creativity Program Proposals," Journal of Physics: Conference Series, vol. 1255 , no. 1, pp. 1-7, 2019.

[23] A. P. W. Budiharjo and A. Muhammad, "Comparison of Weighted Sum Model and Multi Attribute Decision Making Weighted Product Methods in Selecting the Best Elementary School in Indonesia," International Journal of Software Engineering and Its Applications, vol. 11, no. 4, pp. 69-90, 2017.

[24] D. R. Sari, N. Rofiqo, D. Hartama, A. P. Windarto, and A. Wanto, "Analysis of the Factors Causing Lazy Students to Study Using the ELECTRE II Algorithm," Journal of Physics: Conference Series, vol. 1255, no. 012007 , pp. 1-6, 2019.

[25] K. Fatmawati et al., "Analysis of Promothee II Method in the Selection of the Best Formula for Infants Under Three Years," Journal of Physics: Conference Series, vol. 1255, no. 1, pp. 1-7, 2019.

[26] P. Alkhairi, L. P. Purba, A. Eryzha, A. P. Windarto, and A. Wanto, "The Analysis of the ELECTREE II Algorithm in Determining the Doubts of the Community Doing Business Online," Journal of Physics: Conference Series, vol. 1255, no. 1, pp. 1-7, 2019.

[27] S. Sundari, Karmila, M. N. Fadli, D. Hartama, A. P. Windarto, and A. Wanto, "Decision Support System on Selection of Lecturer Research Grant Proposals using Preferences Selection Index," Journal of Physics: Conference Series, vol. 1255, no. 1, pp. 1-7, 2019.

[28] S. R. Ningsih, R. Wulansari, D. Hartama, A. P. Windarto, and A. Wanto, "Analysis of PROMETHEE II Method on Selection of Lecturer Community Service Grant Proposals," Journal of Physics: Conference Series, vol. 1255, no. 1, pp. 1-7, 2019.

[29] T. Imandasari, M. G. Sadewo, A. P. Windarto, A. Wanto, H. O. Lingga Wijaya, and R. Kurniawan, "Analysis of the Selection Factor of Online Transportation in the VIKOR Method in Pematangsiantar City," Journal of Physics: Conference Series, vol. 1255, no. 1, pp. 1-7, 2019.

[30] V. Jain, A. K. Sangaiah, S. Sakhuja, N. Thoduka, and R. Aggarwal, "Supplier selection using fuzzy AHP and TOPSIS: a case study in the Indian automotive industry," Neural Computing and Applications, vol. 29, no. 7, pp. 555-564, 2016.

[31] X. Deng and Y. Deng, "D-AHP method with different credibility of information," Soft Computing, vol. 23, no. 2, pp. 683-691, 2017.

[32] S. C. Nayak and C. Tripathy, "Deadline sensitive lease scheduling in cloud computing environment using AHP," Journal of King Saud University - Computer and Information Sciences, vol. 30, no. 2, pp. 152-163, 2018.

[33] R. Fattahi and M. Khalilzadeh, "Risk evaluation using a novel hybrid method based on FMEA, extended MULTIMOORA, and AHP methods under fuzzy environment," Safety Science, vol. 102, no. November 2016, pp. 290-300, 2018. 